\title{
Precariousness, Gender, Resistance and Consent in the Face of Global Production Network’s 'Reforms’ of Pakistan’s Garment Manufacturing Industry
}

\begin{abstract}
This case study of the restructuring of Pakistan's garment manufacturing industry to increase owners' control over the labour process, explores how attempts to replace an informal, casual internal subcontracting system employing predominately men on piece-rates with assemblyline production employing predominately women in formal salaried employment, intersected with local patriarchal structures, triggered workers' reflexivity and agency, and had unanticipated consequences. Using Archer's (2007) notion of agency, the paper examines the theoretical space where capitalism meets patriarchy, and both are reproduced. The focus on reflexivity, anchored between objective contexts and agents' personal concerns, helped theorise capital-labour-gender relations in global supply chains and explain workers' impactful resistance to a supposedly precarious work regime. Our findings challenging the notion that globalization reduces workers' agency and their potential for impactful resistance, though workers' choices were framed by patriarchal social expectations, and the plan failed to empower women as its proponents promised.
\end{abstract}

\section{Key Words}

garment manufacturing, gender, globalization, impactful resistance, Pakistan, precarious workers

\section{Introduction: Garment Manufacturing in Pakistan and its Reform}

'Men's recruitment is closed, only women should contact' 
This banner prominently displayed on the exterior of a factory in Karachi in 2011 reflects the recent history of the garment industry in Pakistan, a cotton-rich, developing country, historically considered a strong player in this field. Following generous Multi-fibre Arrangement (MFA) quotas in 1974, international buyers started buying from Pakistan, though quota restrictions produced inconsistent order quantities. This and Mr Bhutto's socialist government's policies encouraged garment firms to be small and to use inside contractors, usually an experienced worker/tailor with access to labour, to organise production (Clawson, 1980). Contractors mainly hired male workers from rural areas, often relatives or acquaintances. Firms provided raw materials, machines, and accessories but the contractor managed production, and disciplined and controlled labour (Littler, 1990). Workflows were haphazard with machines not laid out as assembly-lines, which required flexible, skilled workers. Contractors determined workflows, tracked workers' production and compensated them on piece-rates. The contractor added his commission to his labour costs and quoted a piece-rate to factory owners. These arrangements had advantages for owners. A casual subcontracted workforce circumvented laws on union formation and provided firms with a flexible cost structure to adjust to sales variations.

The removal of MFA quotas in 2005 was a generally recognised threat (ILO, 2002). Western buyers were demanding lower prices, and Pakistan's industry had higher costs than competitors, e.g. in Bangladesh and China. This coincided with Pakistan's governments from the 1990s instituting neo-liberal economic policies endorsed by the World Bank and International Monetary Fund. Intermediaries in the global production network, namely the United Nations Development Programme (UNDP), the International Labour Organization (ILO), Western aid agencies and non-governmental organisations (NGOs) discursively created an 'imagined economy' to reconstruct and make the Pakistan garment manufacturing competitive and to empower women (Author A). Their discourse persuaded the State to 
financially support women undergoing training, subsidise employer contributions to their pensions, and offer a marriage grant to women with 3 years of factory work. Many factory owners adopted these 'reforms' which entailed replacing male piece-rate workers with assembly-line production employing mainly salaried women workers on minimum wage rates (up to $50 \%$ less than male workers), supervised and controlled by professional managers. Male piece-rate workers were welcomed if they consented to become full-time formal salaried employees. These 'reforms' brought contestations between factory owners and male and female workers about the control of labour processes resulting in unanticipated outcomes.

Deploying gendered ideologies to create and appropriate more surplus value is an 'endemic' feature of global production (Wright, 2006) but how this global logic plays out locally, when enacted, is variable and contingent (Salzinger, 2003). The continuous (re)production of capitalist and gendered subjects and reconfigurations of power are ever incomplete, contradictory and open to disruption (Salzinger, 2003; Wright, 2006). In our case, the logic of capital interacted with local cultural discourses, gendered work practices and workers' agency (Ong, 1987), resulting in unanticipated outcomes. This prompted the investigation of the following research questions: How did the globalisation efforts to 'reform' production intersect with local patriarchal structures? How did female and male workers exercise agency and choose to resist or consent given their social and occupational concerns framed within patriarchal and capitalist structures? How did this affect the labour process?

The article next reviews research on precarious work, the feminization of work, and links between globalization, agency, and workers' resistance or consent. Then the research methods are described, followed by an analysis of how events on the ground played out. The final section presents conclusions and contributions. 


\section{Globalization, Gender, Precarious Work, Agency, Resistance and Consent}

Work on globalization, feminization and precarious work exhibits three major trends of interest to this research. First, economic and political changes associated with globalization, especially increasingly competitive supply chains, have ushered in an era of precarious work for workers in the global South (Kalleberg and Hewison, 2013; Kidder and Raworth, 2004). Precarity occurs when some social groups are dispossessed of their due rights, usually by dominant groups (Butler and Athanasiou, 2013). Part-time, temporary and piece-rate workers constitute such a group as they are often denied rights granted to full-time, salaried and permanent employees. However, contrary to a standard definition of precarity, Pakistan's garment manufacturing reforms sought to substitute precarious informal work, i.e. 'uncertain, unstable, and insecure', beyond the purview of labour laws (Hewison and Kalleberg, 2013: 395), with formal employment, 'built upon employment status..., standardized working time... and [permanent] employment' (Vosko, 2010: 51). The ILO and multilateral organizations equate worker well-being with formal employment, seeing informal employment as contributing to underdevelopment (Arnold and Bongiovi, 2013). Precarious worker's resistance for protecting precarity in our case raised important theoretical issues to explore visà-vis their agency. Moreover, contestations around control of labour processes have a spatial dimension (Smith, 2016). The reforms in Pakistan mark an international division of labour whereby manufacturers in developing countries use patriarchy and precarity to remain profitable to meet mobile global capital's and Northern buyers' demands. However, workers in the local economy may engage in economic activities differently from their Northern counterparts thus revealing a different perspective on 'precarious' work (Monteith and Giesbert, 2017). Attempts to change their employment status can shape production and employment relations in ways unanticipated by global forces (McGrath-Champ et al, 2010). 
Second, precarious workers are often portrayed as passive victims, unable to resist global capital's advances for material and discursive reasons (Alberti et al, 2018). They have poor bargaining power due to no or weak unionisation, few workplace citizenship rights, and a hand-to-mouth financial situation (Anderson, 2010; Lee et al, 2015). Furthermore, contemporary managerial discourses can shatter workers' agency by fostering beliefs that globalisation pressures are irresistible (Lee, 2015; Gabriel, 1999). If formal workers, i.e. salaried, permanent, and governed by contracts, have problems resisting tightened controls (Kalleberg, 2009), then resistance by precarious workers is deemed virtually impossible. Their mobility power (Smith, 2016) and subtle resistance strategies may marginally improve their lot (Alberti, 2014; Berntsen, 2016), but without active and organized external support, this may not seriously threaten managerial designs (Jenkins, 2013; Manky, 2018) and even perpetuate oppressive employment relations (Berntsen, 2016). Consequently, the agency and ability of precarious workers to execute impactful resistance in the face of powerful global forces are neglected (Alberti, 2014; Berntsen, 2016). Our case granted an opportunity to redress this by exploring how the global capital logic's intersections with local cultural discourses and practices affected workers' agency and gendered work practices (Bair, 2010). Global capital may use its discursive and material powers and use feminization to crush labour agency, but this can also grant male workers grounds to resist (Choi, 2018). Precarious male workers may believe that changes to labour processes bringing permanent formal employment de-emphasize their skills and reduce their freedom, deemed uniquely masculine (Choi, 2018). Also, although global industrialisation constrains choices and promotes insecurities, it also creates opportunities for workplace resistance (Shilling and Mellor, 2015; Simmel, 2010) by increasing the roles individuals hold (Sullivan and Delaney, 2017). Hence workers must reconcile and prioritise their conflicting demands while protecting their personal identities. Multiple roles can produce tensions for role incumbents, but precarious workers can exploit their 'double 
existences' (Shilling and Mellor, 2015; Simmel, 2010) to mount impactful resistance against capital's efforts to control the labour process.

Third, contrary to international NGOs', multilateral agencies', and governments' claims about women's empowerment through their greater participation in labour markets, the critical management literature often presumes that capital can co-opt local structures of domination and exploitation, especially patriarchy in conservative developing countries, to its advantage (Bair, 2010) and use feminization of the workforce to crush labour's agency and resistance (Elson and Pearson, 1981). Female workers face a worse situation than male precarious workers as they are dispossessed by both patriarchal and capitalist structures. Globalization often leads to employing cheaper young women in the global South, who are presumed more docile and amenable to organizational discipline, and willing to bear monotonous, repetitive semi-skilled tasks, susceptible to quick training (Wright, 2006); and neoliberal policies encouraging greater employment by women strips out women workers' rights, justice, equality, and their ability to undertake collective action to mobilise political changes (Cornwall and Rivas, 2015). Patriarchal structures, especially in conservative developing countries, dispossess women of mobility power, rendering them ideal workers serving capitalist interests (Goger, 2013) for, 'patriarchal norms mediate women's differential entry into the labouring experience, structure women's shop-floor experience and also endlessly recreate an imagery of gender subjugation' (Mezzadri, 2016: 1887). A gendered and precarious subject is produced at the factory floor through a process of delineating and sustaining gender differences (Salzinger, 2003). However, whether capital can control the labour process by producing and sustaining gender differences cannot be determined a priori. Their outcome may depend upon the nature and results of struggles within and between workers and managers (Storey 1985). To understand the propensity and capacity of female workers to indulge in inter-group struggles, or to resist or comply with managerial designs, requires, inter 
alia, understanding how they exercise agency to accommodate pressures emanating from the intersection of structures of capital and patriarchy.

Exploring the agency of precarious actors vying for control over the labour process helped extend our understanding of work, globalization, feminization and precarity within our case study. Adequately conceptualizing agency lies at the heart of labour process theory debates concerning: why 'workers get attached to routines that are seemingly [precarious]' or 'how gender identities shape and constrain individual opportunities at work' (Thompson, 1989: 250). These extend from early critiques of 'missing' agency in Braverman's work (Braverman, 1974) to later structuralist and post-modernist revisions and critiques (Lucio and Stewart 1997; O'Doherty and Willmott, 2001; Parker, 1999). Throughout these debates, the role of agency in articulating and influencing struggles between capital and labour has remained highly contested (Thompson and Smith, 2009). However, our concern that post-modernists' focus on agency sacrifices basic and essential features of labour process theory, e.g. the objective properties of modes of production and collective identities of labour; and that the structuralists' efforts to protect these fundamental theoretical tenets reduces agency to a third-person perspective delineated by their social position, led us to the work of Archer (2007).

\section{Agency and Reflexivity}

Archer's (2007) more nuanced concept of agency helped us to examine workers' choices and to respond to Alberti et als.'call (2018) to study objective conditions alongside subjective but heterogeneous experiences of work. Archer, inspired by critical realist philosophy, challenges deterministic and all-encompassing versions of globalisation's effects upon labour, by emphasising individual agency and reflexivity. Structure and agency are analytically distinct and stratified (Archer, 2003). Structurally emergent powers may constrain or enable individuals' actions, but their agency i.e. personal emergent powers mediate this. 
Personal emergent powers incorporate individuals' reflection on their 'personal concerns' within their objective social circumstances, and their (possibly fallible) conclusions inform their choice of action (Archer, 2007). For Archer, 'reflexivity depends upon a subject who has sufficient personal identity to know what he or she cares about and to design the "projects" that they hope (fallibly) will realise their concerns within society' (Archer, 2007: 34).

Archer accepts that globalization resets political, economic and social structures, but despite its constraining effects on weaker groups, she argues that it stimulates holders of positions such as citizens, employees, and woman, to exercise agency and enhances reflexivity (Archer, 2007). Agents' personal concerns intersect with three orders of 'reality'. The natural order concerns the physical world, the limitations it imposes upon agents, and their desire to avoid physical pain and harm, e.g. globalized supply chains have led vulnerable groups such as women and children to undertake jobs beyond their physical capability (ILO, 2016). The practical order covers social concerns linked to individual competencies, professional and vocational achievements, and skills (or lack thereof) exacerbated by work changes in the globalization era (Sennett, 2008). The social order covers the normative expectations society imposes on agents and their worries about not fulfilling their social roles, e.g. global value chains have led women in Third World countries to work outside homes, contrary to normative expectations in a patriarchal social structure (Grünenfelder, 2012). The conception of self involves reconciling these demands. For Archer (2007), the self has an ontological existence not entirely determined by the social order, as agents reflect upon the intertwined and sometimes conflicting demands of each order and dominant discourses to determine how they prioritise each concern.

From a labour process theory perspective, this conceptualization allows labour to retain a collective identity (qua practical concerns), while still granting agents genuine human subjectivity bearing on their individual prioritization and mediation of concerns. Some may 
prioritize social concerns whereas others may make work the predominant basis of their personal identities. Their choices can shape each groups' resistance or consent in the workplace. Also, if personal concerns are not entirely consumed by practical or social concerns,

this grants spaces for agents to fulfil the demands of increased roles wrought by global industrialisation (Sullivan and Delaney, 2017), while simultaneously protecting their personal concerns. Despite the conflicts and tensions multiple roles can produce, workers can exploit the multiple identities this produces to strategically deal with structural pressures and opportunities stemming from globalization. Which pressures they confront or evade, or what strategies they employ to achieve their personal concerns are thus the domain of substantive theorization (Archer, 2007). Our research utilized this theoretical scheme to understand how different social groups reflected and acted on structural constraints and opportunities caused by the intersection of global competitive pressures and local patriarchal structures, and how their agency and reflexivity affected the labour process.

\section{Research Methods}

Given the desire for a holistic, in-depth account, a qualitative research methodology was used, employing multiple data sources to increase data validity and reliability (Eisenhardt, 1989). The industry was selected as it is labour intensive, known for precarious work (Elson and Pearson, 1981), and employs millions of workers worldwide (Kidder and Rowarth, 2004). Additionally, in Pakistan, unlike South Asian rivals, the workforce is dominated by men paid on piece-rates, allegedly a cause of poor performance and the need to restructure the labour process (Makino, 2012). Ensuing conflicts over value creation and appropriation made it an interesting site.

96 semi-structured interviews covering all industry stakeholders (firm owners, managers, supervisors, workers, buyers' representatives, government officials, and development 
organizations' staff) from 46 firms in Karachi, Lahore and Faisalabad, the three largest apparel manufacturing hubs in Pakistan took place between 2009 to 2017 (see Table 1 for details). The lead author, who carried out these interviews, also worked for a social compliance auditing firm assessing working conditions in these factories for European and US brands and two renowned multi-stakeholder initiatives. This resulted in 95 days of participant observations and helped him spend considerable time 'back-stage' with male and female workers and contractors. Field notes and diaries generated from observations were important data sources. Two focus groups with 15 and 20 male workers (70\% were piece-rate workers) were held in a Faisalabad village in August 2014 and December 2015. Discussions covered working conditions, experiences of changed factory regimes, and their concerns and choices. A focus group with 8 factory owners occurred in May 2014 at a local university. Additional data came from secondary sources including reports by the UNDP, the ILO and the Institute for Development Economics, Japan.

\section{Table 1 Here}

The diverse data set made data analysis challenging. The desire to explore workers' reflexivity and agency within its social context led us to Braun and Clarke's (2006) framework for thematic analysis whereby coding is based on analytic questions connected with the research aims (Hughes et al, 2017), namely: What were agents' perceptions of both factory regimes? What factors influenced such perceptions? What were their personal concerns? What choices did agents make? How did they justify these? Detailed narratives answering these questions for each agent were developed. Triangulating other sources (interviews, focus groups, internal documents, and published reports) helped refine and strengthen the narrative.

The first author coded the narratives and identified important topics related to these questions. These comprised of phrases, terms, or descriptions offered by participants which 
included, among others, comments about 'familial needs', 'restricted mobility', 'izzat (prestige), 'mahol (environment), 'control of destiny', 'pabandi (enslavement), 'freedom', 'masculine', and 'factory girl'. These codes were discussed with a co-author for validation and modified until an agreement was reached. Next, two authors grouped these codes in second and third order theoretical categories independently and revised these until an agreement was reached. For example, 'concerns for family', 'concerns for stability', 'concerns for freedom' were classified under 'personal concerns'. After constantly iterating the data, theory, and research questions, the aggregate theoretical constructs crystallized. These included 'personal concerns'; their ordering for different groups of workers; 'structural constraints' and 'structural opportunities', i.e. material and cultural conditions each set of agents faced including expectations for the social positions they occupied; the meanings they attached to the two production regimes; and their 'reflexive projects', i.e. how they related personal concerns to their understanding of structural opportunities and threats, and the projects they devised to address these concerns.

\section{RESULTS}

\section{The Emergence of 'Precarious' Work(ers)}

Piece-rate work became dominant in Pakistan's garment manufacturing industry because employers' and male workers' interests converged. Many workers were new factory proletariats with small rural landholdings or land rights giving them two income sources, though their agricultural income was insufficient for sustenance. At the height of the quota regime they enjoyed good piece-rates, and a lifestyle of hard work and good earnings for a few days, followed by some days spending their earnings and/or visiting families and friends in their villages. Reciprocity between contractors and workers existed due to kinship or village ties. A contractor's priority was ensuring his workers earned a decent wage, so they would 
remain with him. Factory schedules accommodated workers' needs (Thompson, 1967), e.g. they could accommodate an absent worker. The piece-rate workers did not perceive the apparently precarious work arrangements as very precarious.

A senior manager noted how this 'responsible autonomy' regime had advantages because remuneration was tied to the task, not time (Thompson, 1967):

'Piece-rate workers ...work on their own schedule and have flexible working hours.... There is always a calculation going on in their mind. ... when he completes the work of a certain amount in a day he may leave.... They also have more absenteeism. For example, on Eid [a Muslim festival] they will leave for their hometown and come back when they have no money left. Before Eid, they are willing to work day and night.' (Director of operations, male, 25 years total experience, 5 years tenure with the current firm)

Work hours did not conform to regular factory time: arriving late and working late at night was common. If a job had excess workers, the contractor sent them to another site or divided work so no-one remained jobless. Sometimes tasks were assigned to a worker unskilled in an operation, which improved their skills across multiple operations - an incentive as it increased their earning potential and reduced daily wage fluctuations. Consequently, most workers saw themselves as 'karigars' [skilled craftsman]. They had mobility power (Smith, 2016) as many had worked in the industry for a long time and had developed an extensive social network. They knew piece-rates and employment opportunities elsewhere and valued their liberty to change firms. They quickly complained if rates elsewhere were higher and would threaten to leave. This apparently precarious work arrangement was amenable to all parties, despite tensions common to internal contracting, e.g. controlling the workflow and increasing productivity (Clawson, 1980). It generated consent as workers perceived it as fair and they could control their destiny (Burawoy, 1979). 


\section{Female Workers' 'Consent' to the Salaried System}

The new production regime's proponents claimed it would help firms to compete on price, quality and turnaround (Author A). With suitable training, productivity increases could reduce labour cost per piece by $40-60 \%$. This broke the pact between factory owners, contractors and male piece-rate workers and brought women into factories on fixed salaries supervised by managers, not contractors. This had attractions for owners. Female workers were unlikely to resist labour process changes as they lacked factory work experience; were deemed malleable having only done household duties or helping husbands/parents informally; were more likely to stay; and were cheaper (Elson and Pearson, 1981).

However, women faced conflicting social pressures. Men being the breadwinner was a social norm. Being a 'factory girl' carried a stigma (Makino, 2012). Women working for wages in factories was considered legitimate only under extreme economic necessity, which was the situation in many working-class families facing extreme financial hardships (Grünenfelder, 2012). International development agencies recognised these female workers' vulnerability and pitched factory work as solving their household economic problems (Author A). However, we found that women's reasons for joining the workforce had little connection with the international agencies' discourse. Their decision was instead linked with their personal concerns framed within a patriarchal social order. Most women recruited were: 18-25 years old; mainly unmarried; secondary breadwinners; entering the labour market for the first time; did not see work as a career, and came from poor families. Their primary personal concern was getting married and to save for a dowry unaffordable by their parents (Makino, 2012). Most claimed once this was achieved, they would leave.

Factory work was not easy. Many women had long commuting times resulting in a 12hour work day. They worked on a single workstation for a long time; work was physically 
demanding, monotonous and repetitive; and supervisory surveillance was strict. They often knew they might earn more and acquire more skills doing piece-rate work, but they still consented to the salary-regime. This was a reflexive choice whereby social concerns dominated practical concerns.

A minority of women were in their 40's who worked in factories because their household income was insufficient to support important expenses, e.g. children's education deemed as important for improving their life-chances. They could not afford a variable monthly income:

'On piece-rate, there is an uncertainty of work. I cannot afford this. I work for specific reasons and not for any adventure. If I earn less in a month, how I will fulfil my obligations?' (Stitching operator, female, married with two children, 7 years experience, 2 years with the current firm)

Thus personal concerns vis-à-vis children's education or dowry triggered female workers' reflexive choices within the strict demands of a patriarchal order. Often male family members inspected the factory before allowing female family members to work there. Unescorted movement of women and mixing of genders was frowned upon. Firms appreciated this and reassured families that they provided a 'safe' working environment for women, and they restricted mingling between genders, e.g. by providing segregated canteens for male and female workers or alternate timings for tea/lunch breaks, separate transport, and providing drinking water at their workstation. Physical mobility restrictions constrained female workers' ability to explore better job opportunities elsewhere, but even if they found one, it might not gain family approval, consequently most stayed with their initial employer. They could not take any advantage the piece-rate regime might offer due to a gendered division of labour and patriarchy reproduced in factory arrangements. 
However, their consent was reflexive - while subordinating their physical concerns, they prioritized social over practical concerns. Greater empowerment of women through factory work had little traction for them. Female workers wished to stay in factories not a day longer than necessary. One remarked:

'[God forbid] that I work after marriage. Otherwise, what is the point in getting married ....? You work after marriage as well; what would be your life then?' (Stitching operator, female, single, 4 years experience with single firm)

\section{Male Workers' Limited 'Consent' to Salaried Employment}

Since most women consented to work on the salary regime only for a limited time, handling product variety while maintaining good productivity still required multi-skilled male operators. Firms preferred paying them salaries, often higher than female workers. If unacceptable they were paid piece-rates. Consequently, factories converting to a salary-regime often had two production regimes working side-by-side - a salary-regime supervised by trained middle managers predominantly employing women and a piece-rate regime employing men run by contractors. This interim arrangement was expected to last for 14-16 months: by when enough women would be trained, and/or enough male workers would have accepted salaried work.

Salaried work offered some benefits for piece-rate workers, despite its lower remuneration. Some firms created an internal labour market for upward mobility; and provided legal and medical benefits, bonuses and a stable income not dependent upon a personal relationship with contractors. A worker commented:

'In a piece-rate regime, much depends on the contractor. ... If you are not in his loved ones [smiles], you get work on operations with less price tag'. (Stitching operator, 
male, married with 2 children, an urban worker with 8 years experience, 6 months with the current firm)

Male piece-rate workers came from two localities. Villagers worked in factories in cities for several months then returned home for a few weeks to re-join families and do seasonal agricultural work before resuming factory work. Others were urban workers who returned home every evening. The few male piece-rate workers who accepted salaried employment were mostly urban workers. This was a reflexive choice related to opportunities offered by structural change and their personal concerns relating to the social order expecting them to be responsible fathers and husbands. They justified their choice by emphasizing their different identity, claiming piece-rate workers mostly live a single life in the city and were immature, whereas they were responsible household heads and providers. Uncertain piece-rate work did not suit this identity, whereas the salary-regime did, despite its possibly lower income. A typical response was:

'In piece-rate, your working hours are not fixed, and we must work long hours when a shipment is near. My spouse was not happy with my routine. A few months ago, I got sick and could not work for a month. There was no support available like sick leave or medical benefit. ... My wife convinced me that I should not work on piece-rate and accept employment on salary. I am earning less, but she is managing.' (Stitching operator, male, married with 3 children, an urban worker with 12 years experience, 1 year with the current firm)

However, some male workers worked on the salary regime in a 'laid-back' manner, giving their piece-rate counterparts opportunities to condemn the salary-regime. These workers assigned similar weights to practical and social concerns - their personal identity as a responsible male household family member justified their choice to join the salary-regime but 
they also recognised its risks and lower remuneration, and the need to maintain ties with their former piece-rate colleagues. So they depressed productivity by opportunistically working slower than piece-rate workers, thereby helping sabotage the salary-regime whilst taking its benefits.

\section{Male Workers' Resistance}

Most male piece-rate workers declined to join the salary-regime. It denied a concern dear to them, i.e. freedom (Choi, 2018). One commented:

'A free bird would never want to live in the cage. The salary system is a cage.' (Stitching contractor, male, married, rural worker, 20 years total experience, 01 year with the current firm) Another said: 'I do not like [salaried employment]. It is all about "pabandi" [enslavement]. You must come and leave on time. You cannot go for breaks at will." (Stitching operator, male, single, urban worker, 10 years experience, 1 year with the current firm)

Thus, most mounted everyday resistance (Scott, 1985) but they needed to overcome formidable opposition and prevent more piece-rate workers joining the salary-regime. To do so, they enacted an 'efficient worker' role - more useful than that performed by salaried women. They took advantage of their flexible working hours by altering machine settings at night when female workers had left. As the latter were not very skilled, it took them considerable time next morning to fix the settings, which depressed their productivity. Salaried male support staff with stakes in the piece-rate regime gave informal support. For example, an ex-general manager explained how quality checkers monitored the salaried production lines' quality more stringently to depress its productivity:

'Quality checkers are factory employees working on salaries ... The piece-rate setup suits them as it provides them with an opportunity to earn more through overtime.... 
They become a party with piece-rate workers and support them.' (Ex-general manager and now a productivity consultant, male, 15 years experience, 6 months with the current firm)

They also used 'hit and rescue' tactics to appear more efficient. Under lean retailing, lead-times are vital - products must be shipped on time. Piece-rate workers knew factory owners' vulnerability to this, so they depressed production to delay shipments which created panic among owners. Then the piece-rate workers would offer to rescue them by working extra hours to ensure the shipment was despatched on time, thus further establishing their importance.

The contractors' and piece-rate workers' discourse within factories proclaimed how their skills and flexible working hours, allegedly lacking in women, made them a more profitable and productive choice for factories and 'wise' entrepreneurs would never adopt assembly-line production operated by women. For example, one proclaimed:

'On piece-rates, one must work late in the evening [to meet] ... work and raw material availability. Sometimes there is no work all day and suddenly material arrives in the evening. They must start work then because their earnings are tied to work. Women could not do that. They want to leave for home in the evening... [women] cannot achieve the production level we consistently did ... because they are not "karigars"' (Stitching contractor, male, married, urban worker, 13 years experience, 5 years with the current firm)

But the biggest threat for male workers lay from within. If more colleagues switched sides, the piece-rate regime would die. Piece-rate workers constantly engaged in backstage 'hidden transcripts' or private discourse (Scott, 1985), to make sense of how planned changes would hit them, and how to defend their position. These language games challenged the salaryregime meta-narrative, vented their frustration and increased group solidarity (Hodson, 1995). 
They frequently mentioned their pride in being 'skilled craftsmen', the efforts this entailed, and they emphasized their 'masculinity' as opposed to 'helpless' female workers. During shop-floor talk, they labelled female workers as 'trainees', unwilling and unable to become skilled; claimed the salary-regime was a feminine system, employing workers lacking masculine attributes such as independence, toughness, courage, and competitiveness; and argued that women could not become 'karigars' due to their lesser physical strength, and their submissive and compliant behaviour. The discourse's target was not female workers, who worked in a separate area, but to create a gendered divide, to deter colleagues joining the 'others.' They made derogatory remarks about male colleagues who made the switch, labelling them 'majboor' (helpless), like female workers, indolent, and not 'karigars'. For example, a piece-rate worker claimed:

'There are people who want to leave the factory at 5.00 p.m. and during working hours they do not work hard. These are the ones who work on salary. Any worker who is skilled would never work on salary.' (Stitching operator, male, married with two children, rural worker, 13 years experience, 1 year with the current firm)

Thus piece-rate workers' every-day discourse reproduced their identity as skilled workers with unique masculine talents, coupled with material sabotage, and 'hit and rescue' and collusion tactics to convince factory owners that the assembly-line regime would reduce work quality and profits. A similar discourse employing a gendered binary divide was also used to dissuade colleagues from joining the new regime and to maintain occupational solidarity. 


\section{The emergence of a 'Compromise' Production Regime}

These subtle acts of local resistance and 'strategic' consent frustrated the plans of the powerful alliance of capital, state and international development agencies. Expectations that the salary-regime would replace the piece-rate regime in 14-16 months never materialised in most factories. Of the 45 firms visited, 30 could not convert and maintained a piece-rate regime; 6 adopted a twin-factory regime, with piece-rate and salaried assembly-lines operating alongside each other; and 9 completely converted to a salary-based assembly-line employing semi-skilled women. 23 had participated in a UNDP program for feminizing the workforce but only 5 participants completely converted to a salary-regime, and 5 adopted a twin-factory regime. Our results are consistent with industry trends analysed by international intermediaries. For example, a UNDP study found their intervention had had limited success. It only trained 15,448 operators not the target of 29,700 , partly due to the industry's failure to fully adopt salaried employment, and piece-rate workers' resistance (UNDP, 2013).

However, changes to the piece-rate regime emerged. Most large firms eliminated or coopted contractors to increase managerial control. Contractors continued to supervise and recruit piece-rate workers but now, to maintain workers' consent, they had to consult with management when exercising discipline. The direct contact piece-rate workers now had with factory managers helped eliminate contractors' malpractices, such as favouritism in assigning work, and payment delays or non-payment. Contractors were now bound to one factory and cannot move their workforce elsewhere, so their power was diluted, and owners can better control piece-rates. Nevertheless, as large firms have had consistent orders, they needed a stable workforce and must compete for skilled piece-rate workers by providing stable employment and better earnings, and often provided benefits given to salaried workers. This increased piecerate workers' loyalty, though worker control and undisciplined work practices remained an 
issue. Thus, the piece-rate system, while partially preserved, has changed. Whether this will continue given owners' increased control of such operations remains an open question.

\section{Discussion and Conclusion}

Our research contributes to conversations on globalization, feminization and labour process control by focusing on the precariat's agency. Allegedly, globalization associated with global supply chains can reduce workers' agency and eliminate any chance of impactful resistance (Anderson, 2010; Berntsen, 2016; Lee et al, 2015). However, changed economic and political structures, broken routines and ensuing labour process control struggles associated with global supply chains also triggers reflexivity and agency among workers. Without denying the influence of the capital and patriarchal structures, we have indicated the agency of precariat, and the 'enigmatic theoretical space' (O'Doherty and Willmott, 2001) where capitalism meets patriarchy and both are reproduced. A focus on 'personal concerns' relating to 'practical order' endows labour with collective subjectivity, and agents can mediate, prioritize and amalgamate personal concerns relating to the practical or social order in unique ways leading to different individual actions. This reflexivity, which seeks to reconcile demands of objective contexts and agents' personal concerns, helped explain workers' attachment to seemingly precarious work routines, their consent, and the forms of resistance and consent adopted.

The application of the global agencies' discourse framing reforms in Pakistan's garment manufacturing industry, especially the recruitment of women, threatened male piece-rate workers' collective identity, broke established routines and introduced new social positions and role expectations. Despite the offer of full-time employment with a higher (than female workers) fixed salary and fringe benefits, many male piece-rate workers opted to maintain old 'precarious' work routines using ingenious forms of resistance. Nevertheless, some, mainly urban, male piece-rate workers 'consented' to the salary regime, but due to a different 
prioritization of personal concerns. They prioritized their social concerns of being proper ‘family-men' over practical concerns of making more money by working irregular hours. While all these concerns are shaped by patriarchal and capital structures, their differential prioritization and mediation led to different choices by male workers, and it illustrates how the 'complex media' of capital-labour-gender relations play out in the face of globalized supply chains (O'Doherty and Willmott, 2001). A closer inspection of agency allowed us to go beyond imputed collective gender identities of, for example, a 'deferential worker' or 'utility maximising market actor' (Sayer, 2009).

Unlike most post-modernists (Knights, 1990; Willmott, 1990), agential reflexivity (Archer, 2007) does not mean a denial of collective social subjectivity, a critical tenet of labour process theory. However, our case challenges presumptions that changing political and economic structures favouring global capital can colonize and individualize workers' collective identity and eliminate chances of impactful resistance by precarious workers (Anderson, 2010; Lee et al, 2015), even without open and organized external support (Jenkins, 2013; Manky, 2018). While material factors were important, collective gendered identities of male 'skilled' workers who valued 'freedom', influenced their decision to resist (Choi, 2018). Unlike most industrial workers in the global era, whose dependence on their corporate employers 'becomes constitutive of their identity and selfhood' (Gabriel, 1999: 184); 'practical' and 'social' concerns of male piece-rate workers were independent of their employers' or global intermediaries' discourses that granted them a 'double existence', the basis for their resistance strategies (Shilling and Mellor, 2015; Simmel, 2010). Aided by sabotage, collusion and 'hit and rescue' tactics, male workers presented themselves 'as more efficient workers' than women before factory owners, making the latter doubt the merits or feasibility of the new regime, and to abandon it or continue with two factories in one. Nevertheless, while the piece-rate workers' reflexivity helped forge an effective resistance strategy against capital, it did not produce 
relational solidarity (Butler and Athanasiou, 2013). Rather it was an example of some precariat dispossessing fellow precariat by reproducing the patriarchal and capitalist structures that caused precarity in the first place (Butler and Athanasiou, 2013).

The actualization of the resistance potential against the advances of global capital was contingent upon the favourable local patriarchal structures. Our case suggests that the success or otherwise of precarious workers' resistance cannot be determined a priori. It depends upon the nature of external constraints and workers' reflexivity vis-à-vis these constraints. Their personal concerns might not match those of their employers and colleagues, they may overestimate the power of external constraints and unduly restrain their personal concerns, or they may under-value them and pay the price of a misadventure. Rather than celebrating or prematurely writing the obituary of precarious workers' resistance, researchers need to tease out its operation through detailed field-work.

Our account of agency, characterized by 'personal concerns' and reflexivity, provide a more faithful reflection of female workers' actions, which was neither an unfettered preference (Hakim, 2002) nor a resignation to structural pressures working against them. The globalization discourse propagated by global intermediaries incorporated universal ideals of women's empowerment and independence through full-time work opportunities. However, the discourse and resulting factory arrangements, somewhat ironically, reproduced gender divisions: an internal labour market differentiated on gender lines with antagonistic relations- one for predominately male, skilled, piece-rate workers and another for lower paid 'semi-skilled' women (Butler and Athanasiou, 2013; Goger, 2013; Wright, 2006). Caught between the domination of capital and patriarchy, female workers actively negotiated and worked within the structural constraints to improve their life-chances. Their personal concerns, stemming from the patriarchal social order, caused them to subordinate their physical and practical 
concerns. They prioritized family life and accumulation of dowry, hence they strategically consented to the salaried-regime, albeit for the short-term, to save for their dowry and then leave, causing a perpetual shortage of skilled labour for employers and rendered them still dependent on skilled male labour. Their employers and the fellow male piece-rate workers both promoted and preserved patriarchal structures (e.g. by gender-segregated facilities by owners and denigration of feminine attributes by piece-rate workers) for ends sought by capital (flexibility, higher profits, complex designs, and faster turnaround times). Women factory workers' acquiescence to the new regime revealed the power of dominant social expectations over women workers' choices but within this constrained space, female workers' actions, while reproducing patriarchal structures, limited managerial designs to further their control of the labour process. Additionally, full-time factory employment by women, even with the approval of male family members and gender-segregated assembly lines, affects relational dynamics between genders and constitutes a catachrestic routine (Butler and Athanasiou, 2013), which may eventually alter women's personal concerns and diminish their allegiance to the currently dominant patriarchal social structure.

\section{References}

Alberti, G. (2014). Mobility strategies, 'mobility differentials' and 'transnational exit': the experiences of precarious migrants in London's hospitality jobs. Work, Employment and Society 28(6): 865-881.

Alberti, G., Bessa, I., Hardy, K., Trappmann, V., and Umney, C. (2018). In, against and beyond precarity: work in insecure times. Work, Employment and Society 32(3), 447-457.

Anderson, B. (2010). Migration, immigration controls and the fashioning of precarious workers. Work, Employment and Society 24(2), 300-317. 
Archer, M. S. (2003). Structure, Agency and the Internal Conversation. Cambridge: Cambridge University Press.

Archer, M. S. (2007). Making Our Way Through the World: Human Reflexivity and Social Mobility. Cambridge: Cambridge University Press.

Arnold, D., and Bongiovi, J. R. (2013). Precarious, informalizing, and flexible work: Transforming concepts and understandings. American Behavioral Scientist 57(3), 289-308.

Bair, J. (2010). On difference and capital: gender and the globalization of production. Signs: Journal of Women in Culture and Society, 36(1), 203-226.

Berntsen, L. (2016). Reworking labour practices: on the agency of unorganized mobile migrant construction workers. Work, Employment and Society 30(3), 472-488.

Braun, V., and Clarke, V. (2006). Using thematic analysis in psychology. Qualitative Research in Psychology 3(2), 77-101.

Braverman, H. (1974). Labor and Monopoly Capital: The Degradation of Work in the Twentieth Century. New York: Monthly Review Press.

Burawoy, M. (1979). Manufacturing Consent: Changes in the Labor Process Under Monopoly Capitalism. Chicago: University of Chicago Press.

Butler, J., and Athanasiou, A. (2013). Dispossession: The performative in the political. Cambridge: Polity Press.

Choi, S. Y. (2018). Masculinity and precarity: male migrant taxi drivers in South China. Work, Employment and Society 32(3), 493-508.

Clawson, D. (1980). Bureaucracy and the Labor Process: The Transformation of US Industry, 1860-1920. New York: Monthly Review Press. 
Cornwall, A., and Rivas, A. M. (2015). From 'gender equality and 'women's empowerment' to global justice: reclaiming a transformative agenda for gender and development. Third World Quarterly 36(2), 396-415.

Eisenhardt, K.M. (1989). Building theories from case study research, Academy of Management Review 14(4), 532-550.

Elson, D., and Pearson, R. (1981). 'Nimble fingers make cheap workers': An analysis of women's employment in third world export manufacturing. Feminist Review 7(1), 87-107.

Gabriel, Y. (1999). Beyond happy families: A critical re-evaluation of the control-resistanceidentity triangle. Human Relations 52(2), 179-203.

Goger, A. (2013). From disposable to empowered: rearticulating labor in Sri Lankan apparel factories. Environment and Planning A 45(11), 2628-2645.

Hakim, C. (2002). Lifestyle preferences as determinants of women's differentiated labour market careers. Work and Occupations 29(4), 428-459.

Hewison, K., and Kalleberg, A. L. (2013). Precarious work and flexibilization in South and Southeast Asia. American Behavioral Scientist 57(4), 395-402.

Hodson, R. (1995). Worker resistance: An underdeveloped concept in the sociology of work. Economic and Industrial Democracy 16(1), 79-110.

Hughes, J., Simpson, R., Slutskaya, N., Simpson, A, and Hughes, K. (2017). Beyond the symbolic: A relational approach to dirty work through a study of refuse collectors and street cleaners. Work, Employment and Society 31(1), 106-122.

International Labour Organization (2002). Garment Industry in South Asia Rags or Riches? International Labour Organization: New Delhi. 
International Labour Organization (2016). Non-standard employment around the world: Understanding challenges, shaping prospects. International Labour Office: Geneva.

Jenkins, J. (2013). Organizing 'spaces of hope': Union formation by Indian garment workers. British Journal of Industrial Relations 51(3), 623-643.

Kalleberg, A. L. (2009). Precarious Work, insecure workers: Employment relations in transition. American Sociological Review 74 (1): 1-22.

Kalleberg, A. L., and Hewison, K. (2013). Precarious work and the challenge for Asia. American Behavioral Scientist, 57(3), 271-288.

Kidder, T. and Raworth, K. (2004). 'Good jobs' and hidden costs: Women workers documenting the price of precarious employment. Gender and Development, 12(2), 12-21.

Knights, D. (1990). Subjectivity, power and the labour process. In Labour process theory. London: Palgrave Macmillan, 297-335.

Lee, D. Hampton, M. and Jeyacheya, J. (2015). The political economy of precarious work in the tourism industry in small island developing states. Review of International Political Economy 22(1), 194-223.

Littler, C. R. (1990). The labour process debate: a theoretical review 1974-1988. In D. Knights and H. Willmott (eds), Labour Process Theory, London: Macmillan, 46-94.

Lucio, M. M., and Stewart, P. (1997). The paradox of contemporary labour process theory: The rediscovery of labour and the disappearance of collectivism. Capital and Class 21(2), 49-77.

McGrath-Champ, S., Herod, A. and Rainnie, A. (Eds.). (2010). Handbook of Employment and Society: Working space. MA: Edward Elgar Publishing. 
Makino, M. (2012). What motivates female operators to enter the garment industry in Pakistan in the post-MFA period? Institute of Developing Economies, JETRO: Japan.

Manky, O. (2018). Resource mobilisation and precarious workers' Organisations: An analysis of the Chilean subcontracted mineworkers' unions. Work, Employment and Society 32(3), 581598.

Mezzadri, A. (2016). Class, gender and the sweatshop: on the nexus between labour commodification and exploitation. Third World Quarterly 37(10), 1877-1900.

Monteith, W., and Giesbert, L. (2017). 'When the stomach is full we look for respect': perceptions of 'good work' in the urban informal sectors of three developing countries. Work, Employment and Society 31(5), 816-833.

O'Doherty, D. and Willmott, H. (2001). Debating labour process theory: the issue of subjectivity and the relevance of poststructuralism. Sociology 35(2), 457-476.

Ong, A. (1987). Spirits of Resistance and Capitalist Discipline: Factory Women in Malaysia. Albany, NY: SUNY Press.

Parker, M. (1999). Capitalism, subjectivity and ethics: debating labour process analysis. Organization Studies 20(1), 25-45.

Salzinger, L. (2003). Genders in production: Making workers in Mexico's global factories. Berkeley: University of California Press.

Sayer, A. (2009). Who's afraid of critical social science? Current Sociology 57(6), 767-786.

Scott, J. C. (1985). Weapons of the Weak: Everyday Forms of Peasant Resistance. Yale: Yale University Press.

Sennett R (2008). The Craftsman. London: Penguin Books. 
Shilling, C. and Mellor, P. A. (2015). For a sociology of deceit: Doubled identities, interested actions and situational logics of opportunity. Sociology 49(4), 607-623.

Simmel G (2010). The View of Life. Chicago: Chicago University Press.

Smith, C. (2016). Rediscovery of the labour process. In S. Edgell, E. Granter, and H. Gottfried (Eds.), The Sage Handbook of the Sociology of Work and Employment. Los Angeles: Sage, $205-224$.

Storey, J. (1985). The means of management control. Sociology 19(2), 193-211.

Sullivan, K. R. and Delaney, H. (2017). A femininity that 'giveth and taketh away': The prosperity gospel and postfeminism in the neoliberal economy. Human Relations 70(7), 836859.

Thompson, E. P. (1967). Time, work-discipline, and industrial capitalism. Past and Present (38), 56-97.

Thompson, P. (1989). The nature of work: An introduction to debates on the labour process. London: Macmillan International Higher Education.

Thompson, P., and Smith, C. (2009). Labour power and labour process: Contesting the marginality of the sociology of work. Sociology 43(5), 913-930.

UNDP. (2013). Impact Assessment of Gender Promotion in Garment/Clothing sector through Skill Development (GEN-PROM), United Nations Development Programme: Islamabad.

Vosko, L. F. (2010). Managing the Margins: Gender, Citizenship and the International Regulation of Precarious Employment. New York: Oxford University Press.

Willmott, H. (1990). Subjectivity and the dialectics of praxis: Opening up the core of labour process analysis. In Labour process theory. London: Palgrave Macmillan, 336-378. 
Wright, M. (2013). Disposable women and other myths of global capitalism. New York: Routledge.

Table 1 Details of Interviewees

\begin{tabular}{|c|c|}
\hline Interviewees & Number \\
\hline Male workers & 24 \\
\hline Female Workers & 26 \\
\hline Labour Contractors & 05 \\
\hline Middle Managers & 12 \\
\hline Top Managers/Owners & 16 \\
\hline Development Organization Staff & 08 \\
\hline Government Officials & 02 \\
\hline Buyer Representatives & 02 \\
\hline Consultants & 01 \\
\hline Total & $\mathbf{9 6}$ \\
\hline
\end{tabular}

